\title{
Floristics and Diversity of Invasive Alien Plant Species in Humbo District, South Ethiopia
}

\author{
Markos Kuma $\mathbb{D}^{1},{ }^{1}$ Zewde Achiso, ${ }^{1}$ Alefu Chinasho $\mathbb{D}^{\circ},{ }^{2}$ Dalga Yaya, ${ }^{2}$ and Samuel Tessema ${ }^{2}$ \\ ${ }^{1}$ Wolaita Sodo University, College of Natural and Computational Science, Department of Biology, Wolaita Sodo, Ethiopia \\ ${ }^{2}$ Wolaita Sodo Universities, College of Natural and Computational Science, Department of Environmental Science, \\ Wolaita Sodo, Ethiopia \\ Correspondence should be addressed to Markos Kuma; markoskuma73@yahoo.com
}

Received 15 June 2021; Revised 20 September 2021; Accepted 23 September 2021; Published 21 October 2021

Academic Editor: Chandra Prakash Kala

Copyright (c) 2021 Markos Kuma et al. This is an open access article distributed under the Creative Commons Attribution License, which permits unrestricted use, distribution, and reproduction in any medium, provided the original work is properly cited.

\begin{abstract}
Deliberate and unintentional introduction of invasive alien plant species on native biodiversity by aid agencies and other bodies directly or indirectly are being a series of problems on the economy, ecology, politics, and health of life on earth. Identifying and compiling floristics and the status of invasive alien species and identifying which have viable populations are necessary to manage the ecosystems. The present study is therefore intended to provide information for concerned bodies on the area which needs management priority computing the composition, structure, and diversity of invasive alien plants. A field assessment was conducted to determine the distribution and heterogeneity of invasive alien plant species, and then, six kebeles were chosen and transact lines were laid using a purposeful sampling technique. The vegetation and environment data were collected from farmland, grazing land, fallow land, and road sides using 95 subquadrats $(5 \mathrm{~m} \times 5 \mathrm{~m})$ set in the center and corner of 19 main quadrats $(20 \mathrm{~m} \times 20 \mathrm{~m})$. The voucher specimens collected were taken to the Herbarium of Ethiopia (ETH) for taxonomic identification and future reference. The frequency and density of floristics data were analyzed using MS Excel version 2010, and species diversity was calculated using Shannon $\left(H^{\prime}\right)$, Simpson $(D)$, and evenness $(E)$ indices. Among 35 alien plant species invading natural vegetation in Ethiopia, 25 alien plant species were found in the Humbo district of the Wolaita zone. The densest invasive alien plant species in the area were Parthenium hysterophorus consisting of 15197 individuals/ha, followed by Richardia scabra consisting of 11908 individuals/ha, Xanthium strumarium consisting of 7292 individuals/ha, and Ocimum forskolei consisting of 6280 individuals/ha. The highest species diversity was computed in fallow land $\left(H^{\prime}=2.369\right)$, which is followed by farmland $\left(H^{\prime}=1.627\right)$ and grazing land $\left(H^{\prime}=1.419\right)$. The higher the density of the invasive alien species, the higher the ability to change the structure and diversity of native species of the area results in a decrease in the function and services of the ecosystem. Therefore, management methods must prioritize land types that had the highest diversity of invasive alien species.
\end{abstract}

\section{Introduction}

Invasive species (IS) are either indigenous or nonindigenous species that can heavily colonize a particular habitat [1], but invasive alien species (IAS) are nonnative species that are introduced deliberately or unintentionally in areas outside their natural habitats, where they become established, proliferate, and spread, causing damage to the environment [2]. They are widely distributed in all kinds of ecosystems throughout the world due to the ability to establish themselves, invade, out-compete natives, and take over the new environment [3]. Currently, in Ethiopia, Shiferaw et al. [3] reported the presence of 35 alien plant species.
A large number of species of IAS are introduced into a new environment either through humans or natural (e.g., winds, birds, animals, and water). Thousands of plant species have been transported by humans accidentally or intentionally to areas far from their natural habitats [3]. Invasive alien plants are introduced due to deliberate movement of people and cargo for scientific explorations, industry, and tourism [4]. Human-mediated transport, migration, and commerce are continuing to disperse invasive alien plant species (IAPS) across previously insurmountable environmental barriers such as fresh and marine aquatic ecosystems, mountain ranges, and even inhospitable climate zones $[5,6]$. 
Invasive alien species are now affecting every ecosystem type of the planet and the second global threat to biodiversity next to habitat destruction [3]. They cause biodiversity loss by competing for native species for feed and habitat and altering the physical environment in a way that excludes native species [7]. IAPS are posing negative impacts on native biodiversity, agricultural and rangelands, national parks, waterways, lakes, rivers, power dams, roadsides, and urban green spaces with huge economic as well as social consequences [8]. Ecosystems with low diversity, like some arid ecosystems, are more susceptible to invasion than species-rich systems with well-established species interactions. The most obvious and severe invasion vegetation ecosystems in Ethiopia include disturbed ecosystems, along road sides, agricultural lands, and grasslands. Disturbances in the natural ecosystems provide the great opportunities to the alien species to establish themselves [3].

In Ethiopia, various research works have been done to identify the invasive alien species [8-10], impact on ecosystem, and biodiversity $[2,3,8]$, but no study had been so far carried out solely on the composition and diversity of invasive alien plants species. This is due to the lack of support for invasive alien species research; as a result, some invasive alien species have gone undetected for years and made management more difficult and expensive [11]. Without the knowledge of invasive alien species and their natural range and level of invasive alien, it is impossible to predict the risk that these species might pose to native species [12]. Besides, identifying and compiling actual names and status of invasive alien species and identifying which have viable populations is necessary to manage the ecosystems [13]. Before applying any eradication method on invasive alien species, handling sufficient information which related to them is crucial. The present study therefore provides information to protect the land type which needs management priority computing the composition, structure, and diversity of invasive alien plants.

\section{Methods}

2.1. Description of Study Area. This research was carried out in the Humbo district in the Wolaita zone. The district is situated between 1100 and 2300 meters above the sea level in the South Nation Nationalities and People Regional Government (SNNPR), 350 kilometers from Ethiopia's capital city. The research region had an average annual temperature of $22.0^{\circ} \mathrm{C}$ and an average annual rainfall of $1123.15 \mathrm{~mm}$. The woreda has a total size of 86,646 hectares (ha), with $70 \%$ of the land being lowland and $30 \%$ being midland. Agricultural land $(38,481 \mathrm{ha})$, permanent trees $(4,980 \mathrm{ha})$, forest (16.900 ha), grassland (6,581 ha), varied sectors (7,194 ha), fertile land (5,140 ha), and marshy area (7,370 ha) were all included in district's total area. It is bordered Abaya Lake to the south, Sodo Zuria district to the north, Damote Woyde district to the east, and Ofa district to the west (Figure 1). Cereals such as teff, maize, sorghum, cotton, and root crops such as sweet potatoes, Ensete, and carrot, as well as fruits such as mango, avocado, and banana, are the main crops farmed in the study region [14].
2.2. Data Collection and Identification. A field survey was made from November 1 to 15,2020 , to identify kebeles invaded by invasive alien plant species and to printout where to lay the transact line for data collection. The purposive sampling technique was used to select six kebeles and to lay transact lines based on the point identified during the reconnaissance survey. The design was based on the distribution and the heterogeneity of invasive alien plant species.

The real data collection from the vegetation (floristics) and environment (altitude and land type) were carried out from December 1 to 30, 2020. At four sides and the center of the main quadrat $(20 \mathrm{~m} \times 20 \mathrm{~m})$, subquadrats $(5 \mathrm{~m} \times 5 \mathrm{~m})$ were set for the data on herbs and small shrubs (Figure 2). A total of 19 main quadrats were thrown in the transact lines laid on different land types (grazing land, fallow land, and farmland) identified. Among the transact lines, $100 \mathrm{~m}$ distance was set to differentiate one transact from the other, but the distance between the quadrat and the number of quadrates lay on the transact line was determined by the size or length of the land.

The voucher specimens were taken to the Herbarium of Ethiopia (ETH) for taxonomic identification and future reference. The nomenclature of each species has been done as per the rules given in the International Code of Nomenclature (ICN). Finally, to incorporate the invasive alien species not included in the sampled area, observation has been made.

2.3. Data Analysis Method. The frequency and density of floristics data were analyzed using MS Excel version 2010 by using the following formula: (1) frequency= (number of plots in which species A occurs/total number of plots sampled). (2) Relative frequency $=$ (frequency value for species A/total of all frequency values for all species $) \times 100$. (3) Density $=$ (number of individuals of species $\mathrm{A} /$ area sampled). (4) Relative density $=$ (number of individuals of species A/total number of individuals in area) $\times 100$.

Species diversity differs from species richness, in which it takes into account both the numbers of species present and the dominance or evenness of species in relation to one another. As a measure of species diversity, we calculated the Shannon index $\left(\mathrm{H}^{\prime}\right)$ using the following formula:

$\mathrm{H}^{\prime}=-\sum_{i=1}^{s} \mathrm{Pi} * \ln * \mathrm{pi}$, where is $\mathrm{H}^{\prime}$ represents the diversity of species, $s$ represents the number of species, $\mathrm{Pi}$ represents the proportion of individuals abundance of the $i^{\text {th }}$ species, and ln represents the log base e $_{\mathrm{e}}$

Simpson index (D) and evenness index ( $E=$ evenness) are used as a measure of species dominance and a measure for evenness of spread of species, respectively. As biodiversity increases, the Simpson index decreases. Therefore, compute $\mathrm{D}^{\prime}=1-\mathrm{D}$ to get the clear picture of dominance.

$\mathrm{D}=\sum_{i=1}^{s} \mathrm{Pi}^{2}$, where $\mathrm{D}$ represents Simpson's dominance, $s$ represents the number of species, and $\mathrm{Pi}$ represents the proportion of individuals abundance of the $i^{\text {th }}$ species 


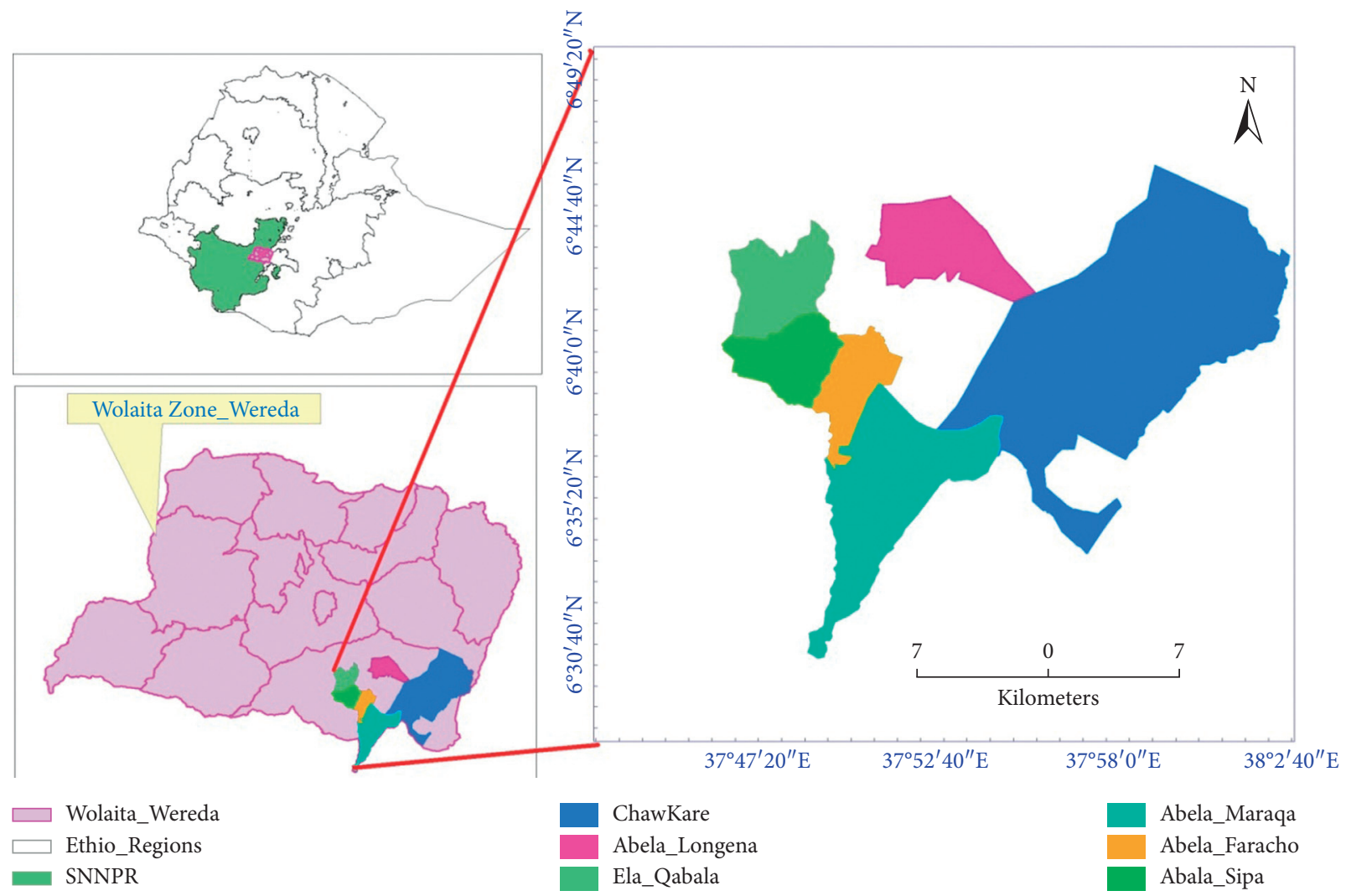

Figure 1: Map of the study area.

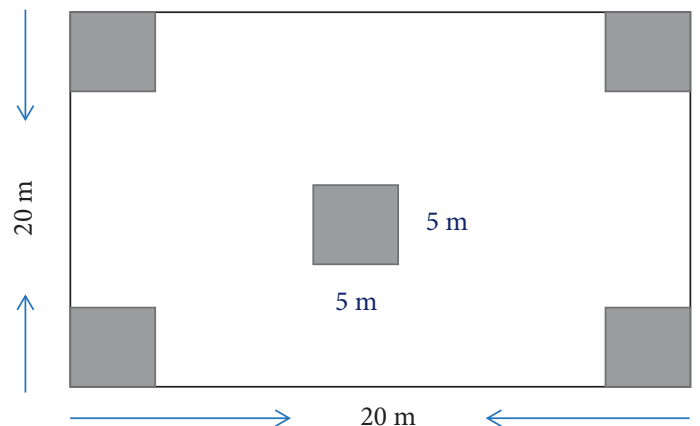

Figure 2: Sampling design map.

$\mathrm{E}=\mathrm{H}^{\prime} / \ln s$, where is E represents the species evenness, $\mathrm{H}^{\prime}$ represents Shannon's index, and $s$ represents the number of species

\section{Result and Discussion}

From 19 quadrats thrown on different transacts, a total of 20 species confined in 19 genera and 10 families were identified, and the remaining 5 species (Lantana camara, Leucaena leucocephala, Opuntia ficus-indica, Psidium guajava, and Ricinus communis) confined in 5 genera and 5 families were recorded to get the complete composition of invasive alien plant species (IAPS) of the area. The 25 species found in
Humbo, Ethiopia, are among 35 alien plant species now invading natural vegetation in Ethiopia [3] and 150 foreign plant species currently invading natural vegetation in eastern Africa [15].

The most dominant invasive alien plant species family was Asteraceae that contributed 5 species (20\%) which is followed by Malvaceae and Fabaceae that contributed 3 species each (12\%). But Solanaceae and Amaranthaceae contributed 2 species each (8\%), and the rest 10 families contributed 1 species each (4\%). The composition in habit of the invasive alien plants indicated that most (44\%) of the invasive alien species in the area were shrub which is followed by herb (36\%). The prostate herbs, climbers, and trees 
contribute $12 \%, 4 \%$, and $4 \%$, respectively (Table 1 ). The finding indicated that Asteraceae (Acanthospermum hispidum, Parthenium hysterophorus, Sphaeranthus indicus, Xanthium spinosum, and Xanthium strumarium), Malvaceae (Corchorus aestuans, Sida acuta, and Urena lobata), and Fabaceae (Crotalaria pallida, Leucaena leucocephala, and Senna occidentalis) contributed a large number of invasive alien plant species (11). But Asteraceae, Papaveraceae, Amaranthaceae, Lamiaceae, and Rubiaceae are found to be highly distributed in the area than other species. From the point of view of growth form/habit of plants, shrub and herb are also highly distributed in the area. Besides, obtaining 25 species from a single district of the country, Ethiopia indicates that how far the area is seriously invaded by these species. Therefore, immediate management methods reported by Gherardi and Angiolini [16] must be applied especially giving priority for the dominant families as well as dominant shrubs and herbs.

The most relatively frequent invasive alien species was Ocimum forskolei (15.15), which is followed by Xanthium strumarium (10.10) and Parthenium hysterophorus (9.09). But the least relatively frequent invasive alien species was Physalis peruviana (1.01) followed by Crotalaria pallida (2.02), Tribulus terrestris (2.02), and Cuscuta campestris (2.02). Relatively, the densest invasive alien plant species in the area was Parthenium hysterophorus consisting of 15197 individuals/ha followed by Richardia scabra consisting of 11908 individuals/ha, Xanthium strumarium consisting of 7292 individuals/ha, and Ocimum forskolei consisting of 6280 individuals/ha (Table 2). Similarly, Witt et al. [15] also confirmed that Parthenium hysterophorus is a widespread invader of rangelands and cropping fields in all the eastern African countries. Rezene and Taye [10] similarly reported that Parthenium hysterophorus and Xanthium strumarium are highly distributed/dense invasive alien species in Ethiopia. The proliferation and spread of invasive alien plants species, displacing or killing or changing composition of native flora, is affecting function and services of the entire ecosystem [3]. The higher the density of the invasive alien species, the lesser the biodiversity of the species, resulting in decreasing the function and services of the ecosystem, because they have the ability to change the structure and diversity of native species of the area. Pauchard [17] similarly stated that invasive alien species, introduced in large scale initially, changes native vegetation diversity and its structure causing structure degradation directly or indirectly, disturbing main biogeochemical cycles.

The findings indicated that the relative density of species is not dependent on the relative frequency of species because the density of a species is only depending on number of individuals distributed on the specified area. Therefore, frequency of a species in a specified area does not determine spread of species, but the density does it. Because similarity of the densities of different species indicates the similarity of evenness of the species, frequency does not do it.

From the identified ecosystems, the richness of invasive alien species was the highest in farmland 14 (56\%), which is followed by grazing land $12(48 \%)$, roadsides 9 (36\%), and fallow land 5 (20\%). Exceeding the richness of
TABle 1: Species composition.

\begin{tabular}{|c|c|c|}
\hline Invasive alien plant species & Family & Habit \\
\hline Acanthospermum hispidum Dc. & Asteraceae & Herb \\
\hline Alternanthera pungens Kunth & Amaranthaceae & Prostate herb \\
\hline Argemone ochroleuca Sweet & Papaveraceae & Herb \\
\hline Corchorus aestuans $\mathrm{L}$. & Malvaceae & Shrub \\
\hline Crotalaria pallida Ait & Fabaceae & Shrub \\
\hline Cuscuta campestris Yunck. & Convolvulaceae & Climber \\
\hline Gomphrena celosioides Mart & Amaranthaceae & Prostate herb \\
\hline Lantana camara $\mathrm{L}$ & Verbenaceae & Shrub \\
\hline $\begin{array}{l}\text { Leucaena leucocephala (Lam.) de } \\
\text { Wit }\end{array}$ & Fabaceae & Tree \\
\hline Ocimum forskolei Benth. & Lamiaceae & Herb \\
\hline Opuntia ficus-indica (L.) Mill. & Cactaceae & Shrub \\
\hline Parthenium hysterophorus L. & Asteraceae & Herb \\
\hline Physalis peruviana $\mathrm{L}$. & Solanaceae & Herb \\
\hline Psidium guajava $\mathrm{L}$. & Myrtaceae & Shrub \\
\hline Richardia scabra L. & Rubiaceae & $\begin{array}{l}\text { Prostrate } \\
\text { herb }\end{array}$ \\
\hline Ricinus communis $\mathrm{L}$. & Euphorbiaceae & Shrub \\
\hline Senna occidentalis (L.) Link & Fabaceae & Shrub \\
\hline Sida acuta Burm.f. & Malvaceae & Shrub \\
\hline Solanum incanum $\mathrm{L}$. & Solanaceae & Shrub \\
\hline Sphaeranthus indicus $\mathrm{L}$. & Asteraceae & Herb \\
\hline Tribulus terrestris L. & Zygophyllaceae & Herb \\
\hline Triumfetta pentandra A.Rich. & Tiliaceae & Shrub \\
\hline Urena lobata $\mathrm{L}$ & Malvaceae & Shrub \\
\hline Xanthium spinosum L. & Asteraceae & Herb \\
\hline Xanthium strumarium L. & Asteraceae & Herb \\
\hline
\end{tabular}

invasive alien species from $100 \%$ indicated that the invasive alien plant species have not been specific to a specific ecosystem.

The IAPS introduced into the study area by anthropogenic means from different continents. America had contributed the highest (72\%) for the spreading of invasive alien plant species to Ethiopia followed by other Africa countries (16\%). Asia, Australia, and Europe had contributed 4\% each (Table 3). Similar study done by Witt et al. [15] also confirmed that most of the invasive alien species present in eastern Africa have their origins in the America's, with a few serious invasive species from Asia.

The informants from the study area indicated that invasive alien species were introduced when NGOs came to give wheat, packed foods, and oils to people in poverty. Similarly, Mwangi and Swallow [18] and Maundu et al. [19] confirmed that several of the invasive alien plant species that are now problematic in eastern Africa were deliberately introduced by governments and aid agencies to augment existing natural resources.

The respective value of Shannon's diversity index $\left(\mathrm{H}^{\prime}\right)$ and Simpson's index $\mathrm{D}$ of land types (grazing land $\mathrm{H}^{\prime}=1.419 ; \mathrm{D}=0.328$, farmland $\mathrm{H}^{\prime}=1.627 ; \mathrm{D}=0.274$, and fallow land $\mathrm{H}^{\prime}=2.369 ; \mathrm{D}=0.137$ ) indicated the inverse relationship of them, i.e., the land type with less Simpson's index is more diverse than the other. On the other hand, it confirms that Shannon's diversity index $\left(\mathrm{H}^{\prime}\right)$ and Simpson's index of diversity $(1-\mathrm{D})$ clearly describe the diversity of species in a given community depending on the evenness and richness of the species. 
Table 2: Density and frequency of invasive alien plant species.

\begin{tabular}{|c|c|c|c|c|c|}
\hline Species name & Frequency & Relative frequency & No. of individuals & Relative density & No. of individual (ha) \\
\hline Physalis peruviana & 1 & 1.01 & 50 & 0.12 & 66 \\
\hline Crotalaria pallida & 2 & 2.02 & 75 & 0.18 & 99 \\
\hline Corchorus aestuans & 3 & 3.03 & 75 & 0.18 & 99 \\
\hline Tribulus terrestris & 2 & 2.02 & 150 & 0.36 & 197 \\
\hline Cuscuta campestris & 2 & 2.02 & 225 & 0.55 & 296 \\
\hline Solanum incanum & 5 & 5.05 & 449 & 1.09 & 591 \\
\hline Urena lobata & 6 & 6.06 & 450 & 1.09 & 592 \\
\hline Sida acuta & 4 & 4.04 & 525 & 1.27 & 691 \\
\hline Xanthium spinosum & 5 & 5.05 & 575 & 1.39 & 757 \\
\hline Senna occidentalis & 5 & 5.05 & 705 & 1.71 & 928 \\
\hline Sphaeranthus indicus & 3 & 3.03 & 900 & 2.18 & 1184 \\
\hline Acanthospermum hispidum & 4 & 4.04 & 1050 & 2.55 & 1382 \\
\hline Triumfetta pentandra & 4 & 4.04 & 1575 & 3.82 & 2072 \\
\hline Alternanthera pungens & 3 & 3.03 & 1650 & 4 & 2171 \\
\hline Argemone ochroleuca & 5 & 5.05 & 1875 & 4.55 & 2467 \\
\hline Ocimum forskolei & 15 & 15.15 & 4773 & 11.57 & 6280 \\
\hline Xanthium strumarium & 10 & 10.1 & 5542 & 13.44 & 7292 \\
\hline Richardia scabra & 8 & 8.08 & 9050 & 21.94 & 11908 \\
\hline Parthenium hysterophorus & 9 & 9.09 & 11550 & 28 & 15197 \\
\hline
\end{tabular}

TABLE 3: Ecosystems affected and continent of origin of invasive alien species.

\begin{tabular}{|c|c|c|}
\hline Invasive alien plant species & Ecosystems highly affected & Continent of origin \\
\hline Tribulus terrestris & 2 & Africa \\
\hline Crotalaria pallida & 4 & Africa \\
\hline Ricinus communis & 4 & Africa \\
\hline Solanum incanum & 2,4 & Africa \\
\hline Cuscuta campestris & 1 & America \\
\hline Physalis peruviana & 1 & America \\
\hline Acanthospermum hispidum & 1 & America \\
\hline Gomphrena celosioides & 1,2 & America \\
\hline Alternanthera pungens & 1,2 & America \\
\hline Argemone ochroleuca & 1,4 & America \\
\hline Parthenium hysterophorus & $1,2,4$ & America \\
\hline Triumfetta pentandra & 1,2 & America \\
\hline Lantana camara & 4 & America \\
\hline Leucaena leucocephala & 4 & America \\
\hline Psidium guajava & 4 & America \\
\hline Richardia scabra & 1,3 & America \\
\hline Xanthium spinosum & 1,3 & America \\
\hline Xanthium strumarium & 1,3 & America \\
\hline Corchorus aestuans & 2,3 & America \\
\hline Senna occidentalis & 2,4 & America \\
\hline Sida acuta & 1,2 & America \\
\hline Opuntia ficus-indica & 1 & America \\
\hline Urena lobata & 2 & Asia \\
\hline Sphaeranthus indicus & 2,3 & Australia \\
\hline Ocimum forskolei & 1,2 & Europe \\
\hline
\end{tabular}

NB: 1, farmland; 2, grazing land; 3, fallow land; 4, road sides.

The highest species diversity is computed in fallow land $\left(\mathrm{H}^{\prime}=2.369\right)$, which is followed by farmland $\left(\mathrm{H}^{\prime}=1.627\right)$ and grazing land $\left(\mathrm{H}^{\prime}=1.419\right)$. The fallow land has several different species with similar abundance, but grazing land has the least different species with similar abundance when compared with farmland (Table 4). This difference in evenness and richness of the species affirms that the management practice is highest in grazing lands than the farmland. The informants reason out that this may be due to we cut invasive alien plant species simultaneously and continuously when mowing grasses for cattle and roof cover in different seasons from grazing lands and remove them from the farmland once during dry season and rainy season. The study carried out by Hejda et al. [20] on the vegetation 
TABLE 4: Distribution of species in land types.

\begin{tabular}{lcccc}
\hline Land type & Shannon's diversity index $\left(\mathrm{H}^{\prime}\right)$ & Simpson's index $(\mathrm{D})$ & Simpson's index of diversity $(1-\mathrm{D})$ & Shannon's equitability $\left(\mathrm{E}^{\prime}\right)$ \\
\hline Fallow land & 2.369 & 0.137 & 0.863 & 0.756 \\
Farmland & 1.627 & 0.274 & 0.726 & 0.678 \\
Grazing land & 1.419 & 0.328 & 0.672 & 0.646 \\
\hline
\end{tabular}

Table 5: Diversity of species in kebeles/district.

\begin{tabular}{lcccc}
\hline Kebele & Shannon's diversity index $\left(\mathrm{H}^{\prime}\right)$ & Simpson's index $(\mathrm{D})$ & Simpson's index of diversity $(1-\mathrm{D})$ & Shannon's equitability $\left(\mathrm{E}^{\prime}\right)$ \\
\hline Humbo district & 2.143 & 0.165 & 0.835 & 0.728 \\
Chew Kare & 1.747 & 0.249 & 0.751 & 0.703 \\
Sipa & 1.525 & 0.264 & 0.736 & 0.734 \\
Abela Faracho & 1.391 & 0.376 & 0.624 & 0.560 \\
Ela Qabala & 1.374 & 0.365 & 0.635 & 0.706 \\
Maraqa & 1.237 & 0.431 & 0.569 & 0.563 \\
Zegire & 1.191 & 0.433 & 0.567 & 0.665 \\
\hline
\end{tabular}

invaded and uninvaded reveled that species richness, diversity, and evenness of native species were reduced in invaded plots. This indicated that the land types with high diversity of invasive alien species have a smaller number of species, diversity, and even distribution of the native species. Therefore, management methods strongly prioritize to the land types with high diversity of invasive alien species not ignoring those land types with less diversity of invasive alien species.

In Humbo district, Chew Kare kebele is with the most diverse in invasive alien species $\left(\mathrm{H}^{\prime}=1.747\right)$, while the least diverse kebele was Zegire $\left(\mathrm{H}^{\prime}=1.191\right)$. Eventhough equitability $\left(\mathrm{E}^{\prime}\right)$ of Ela Qabala $\left(\mathrm{E}^{\prime}=0.706\right)$ is higher than Chew Kare $\left(E^{\prime}=0.703\right)$ and Abela Faracho $\left(E^{\prime}=0.560\right)$, its Shannon's diversity $\left(\mathrm{H}^{\prime}\right)$ found to be less. This clearly indicated the dependency of Shannon's diversity $\left(\mathrm{H}^{\prime}\right)$ on evenness distribution and richness of species. The even distribution of invasive alien species in Chew Kare $\left(E^{\prime}=0.703\right)$, Sipa $\left(\mathrm{E}^{\prime}=0.734\right)$, Abela Faracho $\left(\mathrm{E}^{\prime}=0.560\right)$, Ela Qabala $\left(\mathrm{E}^{\prime}=0.706\right)$, Maraqa $\left(\mathrm{E}^{\prime}=0.563\right)$, and Zegire $\left(\mathrm{E}^{\prime}=0.665\right)$ and their respective Shannon's diversity index $\left(\mathrm{H}^{\prime}\right)$ value indicated the decrease of richness of invasive alien plant species in the respective kebeles. That means any management practice should not focus on evenness of invasive alien species because it does not give clear evidence for management priority (Table 5). Therefore, the management priority should focus on decreasing order of diversity (Chew Kare, Sipa, Abela Faracho, Ela Qabala, Maraqa, and Zegire) rather than focusing on the decreasing order of evenness of invasive alien species.

\section{Conclusion}

Among 35 alien plant species invading natural vegetation in Ethiopia, 25 alien plant species are found in Humbo district of the Wolaita zone. In Humbo district, Asteraceae, Malvaceae, and Fabaceae are contributing a large number of invasive alien plant species, but Asteraceae, Papaveraceae, Amaranthaceae, Lamiaceae, and Rubiaceae are contributing a large number of individuals than the other families. Parthenium hysterophorus, Richardia scabra, Xanthium strumarium, and Ocimum forskolei are highly dense invasive alien plant species in the area. Because they have the ability to affect the structure and function of native plant species, increasing densities of invasive alien plant species results in a decrease in ecosystem function and services. The density of species is independent of their frequency because frequency does not take into account the number of individuals in a given area. As a result, the distribution of species is determined by density rather than the frequency of a species in a given area, and the similarity of different species' densities reflects the species' evenness.

Most of the invasive plant species distribute in any terrestrial habitats of an ecosystem because they are not specific to a specific habitat. The richness of invasive alien species is highest in farmland which is followed by grazing land, roadside, and fallow land. The fallow land has several different species having similar abundance, but grazing land has the least different species having similar abundance when compared with farmland. This is due to continuous removing of invasive alien plants from grazing land when mowing grasses for cattle and roof cover. The land types with high diversity of invasive alien species have less richness and evenness of the native species. Shannon's diversity of invasive species in Chew Kare, Sipa, Abela Faracho, Ela Qabala, Maraqa, and Zegire indicated decreasing of diversity in respective kebeles due to decreasing of richness.

The invasive alien plant species are introduced into the study area from different continents. America had contributed large number of alien plant species invading the area, and it is followed by other Africa countries, Asia, Australia, and Europe. These species have introduced and started invasion of the area when aid agencies came to help people in poverty.

\subsection{Recommendation}

(i) Information (composition, structure, and diversity) of invasive plant species of the specific region is crucial for conservation of biodiversity. Therefore, research studies should be encouraged to do 
research of the specific area to get sum-up compassion of IAPS of the country.

(ii) Invasive alien plant species introduced unintentionally by aid agencies and other bodies must be controlled. Furthermore, the economic, ecological, political, and health-related implications of invasive alien plant species must be known before they are intentionally introduced.

(iii) Immediate management methods must be applied giving priority for the land types and kebeles with high composition and diversity of alien invasive plant species

(iv) Create awareness; appropriate policies and training manuals should be developed for concerned bodies and stakeholders.

\section{Abbreviations \\ ETH: Herbarium of Ethiopia \\ ICN: International Code of Nomenclature \\ NGOs: Nongovernmental organizations \\ IAPS: Invasive alien plant species.}

\section{Data Availability}

Data are obtained upon request to the corresponding author.

\section{Conflicts of Interest}

The authors declare that they have no conflicts of interest.

\section{Authors' Contributions}

All authors made contributions to data collection, analysis, reading, and approving the final article. The corresponding author specifically contributed to the write-up of manuscript.

\section{Acknowledgments}

The authors would like to express their sincere gratitude to Wolaita Sodo University for its financial support in this research project. The authors express also their deepest gratitude to Humbo District Administration Office for giving expertise that facilitates conditions during data collection.

\section{References}

[1] C. C. Ngweno, M. S. Mwasi, and K. J. Kairu, "Distribution, density and impact of invasive alien plants in Lake Nakuru National Park, Kenya," Journal of Ecology, vol. 48, no. 4, pp. 905-913, 2009.

[2] E. Shonga, "New pests challenging the current pest management support system and need for reinvigorate the system," in Proceedings of the 21st Annual Conference, Addis Ababa, Ethiopia, 2014.

[3] W. Shiferaw, S. Demissew, and T. Bekele, "Invasive alien plant species in Ethiopia: ecological impacts on biodiversity a review paper," International Journal of Molecular Biology, vol. 3, no. 4, pp. 169-176, 2018.
[4] P. Pyšek and D. M. Richardson, "Invasive alien species, environmental change and management, and health," Annual Review of Environment and Resources, vol. 35, pp. 25-55, 2010.

[5] P. K. Rai, "Paradigm of plant invasion: multifaceted review on sustainable management," Environmental Monitoring and Assessment, vol. 187, no. 12, p. 759, 2015.

[6] C. Kueffer, "Plant invasions in the anthropocene," Science, vol. 358, no. 6364, pp. 724-725, 2017.

[7] S. Afrin, S. Sharmin, and Q. A. Mowla, "The environmental impact of alien invasive alien plant species in Bangladesh," in Proceedings of the International Conference on Environmental Aspects of Bangladesh, Kitakyushu, Japan, 2010.

[8] EBI, Ethiopia's Fifth National Report to the Convention on Biological Diversity, Ethiopian Biodiversity Institute, Addis Ababa, Ethiopia, 2014.

[9] Global Environment Facility (GEF), "Removing barriers to invasive alien plant management in Africa," Report on National Stakeholders Workshop on Invasive Alien Species, Global Environment Facility (GEF), Addis Ababa, Ethiopia, 2002.

[10] R. Fessehaie and T. Tessema, "Alien plant species invasions in Ethiopia: challenges and responses," in Proceedings of the International Workshop on Parthenium Weed in Ethiopia, Addis Ababa, Ethiopia, 2014.

[11] O. Hendrickson, "Invasive alien species in Canadian forests," in Alien Invaders in Canada's Waters, Wetlands, and Forests, R. Claudi, P. Nantel, and E. Muckle-Jeffs, Eds., pp. 59-71, Natural Resources Canada, Canadian Forest Service, Ottawa, Canada, 2002.

[12] J. Voller and R. S. McNay, "Problem analysis: effects of invasive alien species on species at risk in British Columbia," Kamloops, B.C. Forrex Series, Vol. 20, Forrex, Hawthorne, CA, USA, 2007.

[13] R. Claudi, P. Nantel, and E. Muckle-Jeffs, "Alien invaders in Canada's waters, wetlands, and forests," Natural Resources Canada, p. 320, Canadian Forest Service, Ottawa, Canada, 2002.

[14] P. Wasihun and D. Doda, "Study on prevalence and identification of ticks in Humbo district, southern nations, nationalities, and people's region (SNNPR), Ethiopia," Journal of Veterinary Medicine and Animal Health, vol. 5, no. 3, pp. 73-80, 2013.

[15] A. Witt, T. Beale, and B. W. van Wilgen, "An assessment of the distribution and potential ecological impacts of invasive alien plant species in eastern Africa," Transactions of the Royal Society of South Africa, vol. 73, no. 3, pp. 217-236, 2018.

[16] F. Gherardi and C. Angiolini, "Eradication and control of invasive alien species, in biodiversity conservation and habitat management," in Encyclopedia of Life Support Systems (EOLSS), Developed under the Auspices of the UNESCO, F. Gherardi, M. Gualtieri, and C. Corti, Eds., Eolss Publishers, Oxford, UK, 2004, http://www.eolss.net.

[17] A. Pauchard, Plant invasions across spatial scales: Integrating processes, Ph.D. thesis, Universitatea Montana Missoula, Missoula, Montana, 2002.

[18] E. Mwangi and B. Swallow, "Prosopis juliflora invasion and rural livelihoods in the Lake Baringo area of Kenya," Conservation and Society, vol. 6, pp. 130-140, 2008.

[19] P. Maundu, S. Kibet, Y. Morimoto, M. Imbumi, and R. Adekar, "Impact of Prosopis juliflora on Kenya's semi-arid and arid ecosystems and local livelihoods," Biodiversity, vol. 10, no. 23, pp. 33-50, 2009.

[20] M. Hejda, P. Pyšek, and V. Jarošík, "Impact of invasive plants on the species richness, diversity and composition of invaded communities," Journal of Ecology, vol. 97, no. 3, pp. 393-403, 2009. 